\title{
The Islamic Musical Sciences and the Andalusian Connection: Juan Andrés' «Letter on Arabic Music» (1785)
}

\author{
Isaac Donoso \\ Department of Arabic and Islamic Studies, University of Alicante \\ Carr. de San Vicente del Raspeig, s/n, 03690 San Vicente del Raspeig, Alicante, Spain. \\ isaacdonoso@ua.es
}

DOI: https://doi.org/10.22452/usuluddin.vol49no1.6

\begin{abstract}
Music was an essential part of the philosophical knowledge in the classical antiquity and then in the medieval era. Music provided tools to foster a global speculative knowledge, and the classical Islamic thought developed different musical sciences. This paper tries to describe the different approaches to the musical phenomenon from an Islamic perspective, and the feasible transmission of this knowledge to Western music via alAndalus. In doing so, the paper places attention in the Italian «Letter on Arabic Music» written by the Spanish Jesuit Juan Andrés in 1785, one of the first documents attesting this connection.
\end{abstract}

Keywords: Philosophy of Music, Islamic Musical Sciences, Juan Andrés, al-Fārābī, al-Andalus.

\section{Introduction}

It is still quite common in textbooks of Musical History to provide a general narrative of European Music from ancient Pythagorean theories to a slowly medieval awakening without any transitional period. Music was part of the medieval Quadrivium, together with Arithmetic, Geometry and Astronomy, and allegedly evolved by an internal process. However, as we will describe, Arabic Music achieved between the $9^{\text {th }}$ and the $14^{\text {th }}$ centuries a degree of development without comparison in the Christian European space. Every aspect of musical theory, interpretation, organology, chant, lyrics, history, aesthetics and even reception, was considered in Arabic language. In consequence, it was feasible to understand that, if this was the case, the Muslim European space could have influenced the evolution of Christian medieval music. In this paper we will review the constitution of major Islamic musical sciences, and the reappraisal produced during the Western Enlightenment to 
validate Islamic musical thought and practice for the development of modern European music.

\section{Origins of the Arabic Theory: Al-Andalus and Early Modern Western Culture}

Al-Andalus and Andalusian culture played a pivotal role in early modern Europe. Nowadays, the influence of Islamic Spain in the evolution of Western Mathematics, Philosophy, Medicine, Botany, Pharmacy, Geography and Astronomy, cannot be omitted. The question is why is it still difficult to assume an Arabic influence in the forge of modern European Music? As a matter of fact, an important and laborious intellectual tradition has been continuous since the $16^{\text {th }}$ century to prove this influence. Giovanni Maria Barbieri (1519-1574) in Dell'Origine della poesia rimata ("On the origin of rhymed poetry", edited by Girolamo Tiraboschi in Modena, Presso la Società tipografica, 1790) was perhaps the first to affirm an Arabic origin for the European rhymed poetry and, consequently, popular lyrics:

However, it is quite true that the Spaniards for their closeness, and trade from one nation to another, were the first from that band to acquire from the Arabs who named them Moros, due to coming from Mauritania the language together with the way to make poetry. Which is still true, that from the same Spanish passed to the other neighboring regions, and specially to Provence ${ }^{1}$.

But the most decisive action to prove the Arabic influence in the modernization of European arts and sciences was the one undertaken by the Spanish Jesuit Juan Andrés (1740-1817)². His

1 Our translation from: "Però è ben verisimile, che gli Spagnuoli per la vicinanza, e commercio d'una nazione all' altra fossero i primi da quella banda ad ap prendere da gli Arabi, ch' essi nominarono Mori, per essere venuti da Mauritania, con la lingua insieme la maniera di poetare. La quale è verisimile anchora, che da i medesimi Spagnuoli passasse alle altre vicine regioni, è specialmente nella Provenza", Dell'Origine della poesia rimata (Modena: Presso la Società tipografica, 1790), p. 45.

2 See our chapter "El arabismo de Juan Andrés", Juan Andrés y la Escuela Universalista Española, Pedro Aullón de Haro and Jesús García Gabaldón, Eds. (Madrid: Ediciones Complutense, 2017), pp. 165-178; Roberto M. Dainotto, "The Discreet Charm of the Arabist Theory: Juan Andrés, Historicism, and the De-Centering of Montesquieu's Europe", European History Quarterly 36, No. 1 (2006), pp. 7-29; and Franco Meregalli, “Andrés, 
monumental Dell'origine, progressi e stato attuale d'ogni letteratura, Parma, Stamperia Reale, 1782-1799 ("On the origin, progress and current state of world literature") produced a huge controversy all over Europe. Many contemporary and future European scholars consciously silenced father Juan Andrés, since he defended along more than two hundred pages- filled with positive data-the Arabic influence on European science and culture, including music. This was his so-called "Arabic Theory".

Some directly confronted his viewpoints with bitter answers. This was for instance the case of Esteban de Arteaga and his Della influenza degli arabi sull' origine della poesia moderna in Europa: dissertazione, Rome, Stamperia Pagliarini, 1791 ("On the influence of the Arabs in the origin of the modern European poetry: A dissertation"), a hundred pages of invectives.

Nevertheless, more than a century later Henry George Farmer (1882-1965) remarked the oblivion, though enthusiastically stated its correction:

One of the most deplorable things in history, said J. W. Draper, the author of "The Intellectual Development of Europe," is the systematic way in which European writers have contrived to put out of sight the scientific obligations to the Arabs. This was substantially true at the time it was written, but nowadays no person, save the merest tyro, can afford to adopt such an attitude. Specialised research has allocated the precise position of the Arabs in the culture history of Mediaeval Europe ${ }^{3}$.

From this moment, many authors have been writing about the influence of Arabic Music and Islamic Thought in the development of Western culture (taking al-Andalus - or Islamic Spain and Portugal - as intermediary), from Francisco Salvador-Daniel (1831$1871)^{4}$ to Julián Ribera $(1858-1934)^{5}$.

Herder y el arabismo", Spanien und Europa im Zeichen dar Aufklärung, Siegfried Jüttner, Ed. (Frankfurt am Main: Meter Lang, 1991), pp. 188-196.

3 Henry George Farmer, Historical Facts for the Arabian Musical Influence (London: William Reeves, 1930), p. v. See about this important scholar Israel Katz, Henry George Farmer and the First International Congress of Arab Music (Cairo 1932) (Leiden: Brill, 2015).

$4 \quad$ La musique arabe, ses rapports avec la musique grecque et le chant grégorien (Algeria: Adolphe Jourdan, 1879).

$5 \quad$ Historia de la música árabe medieval y su influencia en la española (Madrid: Voluntad, 1927). A complete analysis of the historiography can be seen in 
We will make a summary of the main Islamic Musical Sciences to obtain an image of the most important elements in the constitution of this valuable part of Islamic Thought. Afterwards, we will focus in Juan Andrés and his writings to revendicate during the years of the European Enlightenment the role of Andalusian legacy for early modern Western culture.

\section{Islamic Musical Sciences}

\section{Science of the Poetry: 'Ilm al-Shi'r / علم الشعر}

Any civilization around the world has developed in some degree knowledge about musical phenomena and its performance, as basic characteristic of humankind. The musical events are not only related with the inner capacity to express emotion, but also with the communication of the societies towards the other or even the transcendent. In this case Music, rather than an anthropological instrument, could express metaphysical dimensions and be related with religious purposes. Therefore, the musical events could be understood under several points of view regarding the goals and nature of its production as a Human phenomenon. ${ }^{6}$

When Islam emerged as religion in Arabia in the $7^{\text {th }}$ century and started to assimilate cultural different areas, the sense of the musical phenomena was changing attending the new conception of the Islamic belief. What we can see as a main frame of the Islamic values is its capability to assume and incorporate inside the same body heterogeneous elements, and this can be said about the Musical phenomena as well. The interpretation that Islam gave to Music was that: heterogeneous sources under a unified goal.

Accordingly, in pre-Islamic Arabia music was valuable as performance and leisure rather than a matter of thought. The chant was especially appreciated in the female slaves, Qayna / قينة 7 . In the pre-Islamic poems, with a high sense or structure and order, the music was organized under the poetical meters, that is, using a

Manuela Cortes, La música árabe y andalusí de las dos orillas en los estudios musicológicos (ss. XVIII-XXI) (Granada: Ediciones del Genal, 2018).

6 Alan Merriam, The Anthropology of Music (Evanston: Northwestern University Press, 1964); and Nicholas Cook, Music, Imagination, and Culture (Oxford: Clarendon, 1990).

7 Habib Touma, The Music of the Arabs (Portland: Amadeus, 1996). 
quantitative system. These meters were a regular frame of time (long-short) and space (specific organization), and to be master in musical art represented to dominate the form rather than the content. ${ }^{8}$ The modal system provided frames according to the purpose of the music, supporting a linguistic meaning. The Music per se could not be effective without the main vocal vehicle and linguistic meaning, being in fact only a medium to put on air the language.

Therefore, the musical art remained a part of the Poetics - Ilm al-Shi $r$ / and the interpretation of the musical phenomena during the pre-Islamic times of the Jāhiliyya / جاهليّة concerts to this attitude. ${ }^{9}$ The origin of the music must be attached together with the Arab poetry, using both as a same way to express the vernacular feelings. The camel's rhythm is said to be the origin of the Arab expression:

L'origine du chant des Arabs, selon Mas'oudi, fut le chant des chameliers, qu'on appelle Hidâ, et qui fut ensuite façonné plus particulièrement sur le mètre Redjez. ${ }^{10}$

Poets were considered in those days as magicians or initiated people in some hidden science that by means of genius or other spirits (Jinn / جنّ) could translate an esoteric message. The poems were in this sense a kind of revelation transmitted by enchanted poets, some magical inspiration capable to drive the listeners into a deep domain of the being. Because the music was a way to communicate this cognition, we can say that the perception of the phenomena put the music in the same level that an esoteric knowledge or, at least, with the sense of being transcendent. Certainly both, music and poetry, transmitted the stories and traditions of the Arab people, as an charmed tradition closer to a kind of revelation. These arguments around the enchantment of the

8 Gabriel Saadé, "L'histoire de la Musique Arabe", Bulletin d'Etudes Orientales, No. XLV (1993), pp. 201-220.

9 Ibn Qutaiba, Introduction au Livre de la Poésie et des Poètes (Paris: Belles Lettres, 1947).

10 Carra de Vaux, Les Penseurs de l'Islam (Paris: Librairie Paul Geuthner, 1923), vol. IV, p. 341. 
poetry, the performance and the sorcery, was the propaganda campaign that Muhammad suffered during the first moment of his preachy:

The commonest allegation against Muhammad was that he was a majnūn, that is, possessed by a jinn. They also suggested that he was a kāhin, or soothsayer, a sahir, magician or sorcerer, and sha ir, that is a poet. ${ }^{11}$

This is what took place when Muhammad emerged in the arena, understanding poetry and musical recitals as a matter of magicians and enchanted people Majnūn / مجنون. Due to the persecutions and problems that Muhammad faced during the first of his mission and the satiric poems and songs against the Qur'ān as true message of God, the Revelation denigrated oral tradition and music:

[69:40] That this is verily, the word of an honored man [69:41]It is not the word of a poet: little is that you believe! [69:42] Nor is the word of a soothsayer: little is that you remember

[69:43]This is the Revelation sent down from the Lord of the 'Âlamin 12

After the attacks that he suffered, oral traditions were false tales of the ancient times for Muhammad. The same could be said about the songs, leisure for the entertainment of the common people, but meaningless for the believers in the last Revelation. As dogma of faith, the Qur'ān did not condemned Music by itself. However, the experience suffered by Muhammad blamed the flexibility of the oral traditions and its fallacy expressing God's message. As only source to understand the reality emerged the Revelation the Qur'ān.

Expressed in saj'/ سجع, rhymed prose, the Qur'ān manifested the many poetic capacities of the Arabic languages. In parallel, Poetry continued being the main art among the Arabs and Arabized

11 Abdul Hameed Siddiqui, The life of Muhammad (Calcutta: Hilal Publications, 1982), pp. 83-84.

12 Quotations from the Qur'ān are provided after the Arabic version and English translation of: Muhammad Taqī-ud-Din al-Hilālī and Muhammad Muhsin Khān, Translation of the Meaning of the Noble Qur'ān in the English Language (Medina: King Fahd Complex for the Printing of the Holy Qur'ān, 1417 H). See also Emile Dermenghem, Muhammad and the Islamic Tradition (New York: Overlook Press, 1981), p. 26. 
nations, from the Persians to the Iberians. In fact, al-Andalus became a real poetic power, with hundreds of poets (Ibn Zaydūn, Ibn Hāni', al-Mu'tamid, Ibn Khafāya, Ibn al-Khațib...) and poetical forms (i.e. the Muwashshah / موشح) that were exported even to the Orient. The Occitan troubadours and the poetry in Romance languages have a long bibliography explaining their decisive Arab influence, including the origin of Spanish language in the Jarcha, kharjah / 13

\section{Science of the Recitation: 'Ilm al-Qirā'at / علم القراءات}

With the appearance of the Revelation- understood as last message of God in the Earth- the status quo changed for music and oral traditions. The sensuality of the musical art, its evasion and fabulous purpose was not compatible with the sobriety of Islam as a conscious faith. Muhammad's thought onto Music tried to explain the necessity of a transcendental use of the music specifically in terms of recitation and psalmody. However there are traditions of the Prophet that allow the chants in days of festivity and other times:

Mais l'Islam fut peu favorable à la musique. Mahomet, d'après une tradition, la toléra pour les noces et les fêtes de famille, ce qui n'exige que fort peu d'instruments; il l'exclut du culte et n'admit que l'Adhān, l'appel à la prière, très belle mélopée dont les vibrations un peu nasals dominent le bruit des villes. ${ }^{14}$

In the construction of the Islamic ritual the music did not take a relevant place and even vanished within Islamic rituals. Nevertheless, in this incipient Islam it is possible to see the construction of rituals as took place in earlier Christianity. But due to the ability of the musical melody to evocate sensual states, to listen up music was not only pernicious, but even a sin:

In fact, we find St. Augustine ( $4^{\text {th }}$ century) torn between three attitudes to music: exaltation of musical principles as embodying principles of cosmic order; ascetic aversion from

13 Otto Zwartjes and Henk Heijkoop "Muwaššah, Zajal, Kharja: Bibliography of Eleven Centuries of Strophic Poetry and Music from al-Andalus and Their Influence on East and West" (Leiden: Brill, 2004).

14 Carra de Vaux, "Preface", in Rodolphe D'Erlanger, La Musique Arabe (Paris: Librairie Orientaliste Paul Geuthner, 1930), vol. I, p. VIII. 
music-making as carnal; and a recognition of jubilation and congregational song as respectively expressing inexpressible ecstasy and promoting congregational brotherhood. Being a rhetorician and not a musician by training, he thought of the numerical side of music as embodied in poetic meters rather than in music proper, but the other two attitudes left him agonizing: it is as if a man were seduced by worship. ${ }^{15}$

In Muhammad's thought onto Music we can find the same aversion against the sensuality of the music when the goal is the mere entertainment. In spite of that, Saint Augustine had some debility towards the music in the moment that it produces the ecstasy of the jubilee, the union in feelings with the transcendental way. In the same terms we find in Muhammad traditions that allow the music and the chants but, in this case, in opposition, this is to say, when the goal of the music is the pleasure, as noted before. ${ }^{16}$

In short, we can find two different trends in the incipient Islamic conception about Music. Firstly, it was validated as a specific ability, following traditions of the Prophet allowing the music in festivities without religious repulsion. Secondly, the traditions that (as similarly seen in Saint Augustine) blamed the sensuality of the music and therefore recommended to avoid it:

Entendre la musique, c'est pécher contre la loi; faire de la musique, c'est pécher contre la religion. Y prendre plaisir, c'est pécher contre la foi et se rendre coupable d'infidélité. ${ }^{17}$

Music is therefore a moral affair that needs under the religious point of view a regulation and prescription. According to the sensibility of the first Islam, the bad experiences of the Prophet about the satirical poems, the musical sensuality and the accusation of fable to the Revelation, made that the rituals started with the most sobriety possible. Due to this, we can find in the Islamic rituals the absence of musical development or institution as it is possible to find Sacred Christian Music. What we can find, in other side, is the existence of a high psalmodic tradition, the 'Ilm al-Qirā'/ علم القراء,

15 Sparshott and Goehr, "Philosophy of Music", in Eds. Stanley Sadie and John Tyrell, The New Grove Dictionary of Music and Musicians (London: McMillan Press, 2001). Website www.grovemusic.com.

16 Carra de Vaux, Les penseurs de l'Islam., p. 360.

17 Carra de Vaux, Les penseurs de l'Islam., pp. 360-361. 
the "Science of the Recitation". ${ }^{18}$ We can include as well within this tradition the Adhān / أذان the call of the muezzin , under the same musical nature.

Recitation of the Qur'ān, as the call to pray, suffered a long process of development until arriving at the present moment. The rules of the recitation are of high complexity and difficulty, and to be a good al-muqrì' / المقرئ one needs to know not only prosody and grammar, but also psalmody and vocal music. There are seven kinds of recitations with three possibilities of speed. Therefore, the music in the Islamic rituals remains in the vocal nature of the psalmody, but precisely due to this fact of moral sobriety, the Science of the Recitation was developed until the highest degree of complexity.

We can find in al-Andalus one of the most important intellectual traditions on Qirā'at, that of Abū 'Amr al-Dānī (c.9811053) and the rendering of the poem al-Shattibiyyah, one of the standard models to learn Qur'ānic readings. ${ }^{19}$

\section{Science of the Chant: 'Ilm al-Ghinā'/ علم الغناء}

After the death of the Prophet, Islam became a universal religion expanding its message world-wide towards the three continents: Asia, Africa and Europe. Muhammad's Revelation, together with his example and life, became the model to build the institutions and laws of the new religion. On the way, the Islamic expansion absorbed the most prominent civilizations. In a short period of time, Islam assimilated the heritage of thousand of years, being in fact a new order without a tradition by its own.

Accordingly, the imperial structures provided to the Islamic civilization the refinement towards aesthetics, speculation and knowledge. Originally a religion from the desert, Islam became the most prominent city builder around the world, and the cities became the nucleus of the most prominent intellectual activity. Courts and palaces were essential in the development of urban administrations,

18 See Encyclopaedia of Islam (Leiden: Brill, Second Edition, 1986), vol. V, p. 127.

19 Wilhelmina Wagner de al-Ganabī, "La Escuela Coránica De Denia: Abū 'Amr 'Uțmān B. Sa īd Al-Dānī: Figura, Obra Formativa Y Obra Escrita" (PhD Thesis, Granada, University of Granada, 1988). 
and leisure and pleasure emerged. Court exquisiteness and protocol found in the vocal music an important instrument, the "Science of the Chant"/ 'Ilm al-Ghinā':

'Ilm al-musiki was the name given by the Arabs to the Greek or mathematical theory of music as distinct from 'Ilm al-ghina', which was the Arabian practical theory, as we know from the Kitāb al-Aghānī and Abī Manthūr. The latter tells us of the "disagreement between the masters of Arabian ghina $\bar{a}$ ' and the masters of [Greek] musiki". Of course, the Arabs and Persians possessed a theory of music long before they became influenced by the translations made from the Greek at the end of the VIIIth and beginning of the IXth centuries. ${ }^{20}$

The chant and the practice of the music among the Arabs was the first basis of the Islamic thought on Music. With the incorporation of the Persian tradition, the practice was increased in terms of instruments and new variations. This is to say, the old Arabian system in playing the lute (al-' $\bar{u} d /$ / العود) in one octave CD-G-a (Do-Re-Sol-La) - changed towards the Persian system in two octaves, changing the strings of both sides -A-D-G-c (La-ReSol-Do). With this new system, the instrument allowed more speculations about the division of the scale. Hence, Arabic and Persian traditions were analyzed at the light of Greek Philosophy.

Nevertheless, to speculate about the division of the octave was a task of the falāsifa / فلاسفة, meanwhile 'Ilm al-Ghināa' was the entertainment of the kuttāb / كتّاب, State's officers, trying to describe the rules and matters of the music as one element of the court. In this case, the music is understood as a glamorous aspect of the court, a pleasure of the palace and a performance for amusement of the rulers. In relation we find the mentioned qiyān, singer slaves that can obtain political relevance in court's affairs. ${ }^{21}$

Without doubts the major reference about music and musicians in classical Islam is the voluminous Kitāb al-Aghānī / كتاب الأغاني

20 “Mūsīḳ̂̀”, in Brill's First Encyclopaedia of Islam (Leiden: Brill, 1987), vol. VI, pp. 749-750.

21 See A.F.L. Beeston, Al-Jahiz. Epistle on Singing Girls (Warminster: Aris \& Philips, 1980). 
(Book of the Songs), by Abū al-Faraj al-Ișfahānī (897-967 A.D.). ${ }^{22}$ It deals specially with the life of the musician Ishāa al-Mawșilī and the city of Baghdad. In al-Andalus we can find similar books of adab / أدب أعith Al- 'Iqd al-Farìd/ العقد الفريد (The Unique Collar) by Ibn 'Abd Rabihhi (d. 940 A.D.) and Tawq al-hamāma / طوق الحمامة (The Collar of the Dove) by Ibn Hazm (994-1063 A.D.).

In this courtesan arena the music was understood as a sensual and exquisite pleasure of the palaces, with stories about musicians and singers, slaves and the different seductive arts. Theorization around the music was concerned to its practice and performance, the different instruments and all related with the musical atmosphere. Accordingly, the Science of the Chant gives us more details of the social life that the properly about music, being a kind of Sociology of the Music. ${ }^{23}$ What we can see in the 'Ilm al-Ghina ', is the Persian influence about the imperial ornament and courtesan refinement, about the performance and the social dimension of the musical phenomena. At the same time, it comes from Arabic tradition in terms of jinns and spirits as a kind of inspiration:

Le chanteur se hâta d'aller raconter cette aventure au khalife qui lui dit: 'Vois sit u as retenu l'aie'. Je prism on luth, dit-il, pour essayer, et je trouvai l'air gravé dans ma mémoire, aussi fortement que s'il y avait toujours été. ${ }^{24}$

We can learn in this tale how the musician plays the melody without knowing it, just because it was "carved" in his memory in a timeless moment, through the presence of some jinn. Consequently, there is not necessity to develop especial ability in musical art, just to obtain inspiration, to obtain the knowledge provided by a jinn. This notion could have its origin in pre-Islamic times, the shi' $r$ as a kind of enchantment due to the supernatural beings.

22 See a short biography in C. Huart, Littérature arabe (Paris: Colin, 1931), p. 183-185 and Aḥmad Ḥasan al-Zayāt, Tārīkh al-Adab al-'Arabī (Beirut: Dār al-Thaqāfa [s.a.]), pp. 410-415. Arabic editions: Kitāb al-Aghān̄̄ (Cairo: Dār al-Kitāb al-'Arabī, 1970-1974), 24 vols; Kitāb al-Aghānī (Beirut: Dār Ihyā' al-Turāth , n.d.).

23 Hilary Kilpatrick, "Princes, Musiciens at Musicologues À La Cour Abbaside", in Les intellectuels en Orient musulman. Statut et Function (Cairo: Institut Français d'Archéologie Orientale, 1999), pp. 1-15.

24 Carra de Vaux, Les penseurs de l'Islam, p. 354. 
Eventually the speculative knowledge of the Islamic Falsafa / introduced Platonic ideas ${ }^{25}$, and new concepts emerged with the philosophy of al-Kindī (796-c. 873 A.D.):

The poet's experience comes to him from active intellect as an inspiration to his latent intellect transforming it into acquired intellect. To give expression to this inspiration in words and thus to put acquired intellect into activity, i.e. to give it the status of intellect in action, is the poet's own work. ${ }^{26}$

The inspiration arrives to the poet (similarly to the musician) from the Active Intellect or "First Motor", this is to say, from God. When it takes place, the poet has already assumed this knowledge. However, in order to implement it, the use of the own abilities plays a vital role "to obtain the level of Intellect in action", this is, to use Reason. Therefore, the activity of the intellect is precisely to use the reason in order to compose poems, music or whatever inspired knowledge. From this point, Reason will play a major function in the theoretical point of view about music the 'Ilm al-Müsīqi .

\section{Science of the Music Theory: 'Ilm al-Mūsīqī / علم الموسيقي}

Properly speaking, the original Philosophy of Music was that written by the Greek tradition and all its branches. This tradition remained relevant in European music until the $18^{\text {th }}$ century. Astonishingly, Pythagorean theory was the dominant framework of the Western music from the $5^{\text {th }}$ B.C. This predominance placed in darkness other theories, as was the school of Aristoxenus (c. 300 B.C.), that was recovered in the $18^{\text {th }}$ century. What is concerning to us, Islamic philosophers had access to the Greek tradition using the Pythagorean school towards Plato and the later neo-Platonism. Namely the nature of the Movбıkn / Mousiké was to solve the mathematical division of sounds in the string of the lyre and their connection with the cosmos:

Although 'music' (mousike) is a Greek word, classical Greece did not use it to mean what we call music. It had no word for

\footnotetext{
25 About the history of the Islamic intellectual thought we use the three volumes of Miguel Cruz Hernández, Historia Del Pensamiento en el Mundo Islámico (Madrid: Alianza, 1996).

26 M. Saeed Sheikh, Studies in Muslim Philosophy (Lahore: Muhammad Ashraf, 1974), p. 70.
} 
that. Etymologically, the word means 'the business of the Muses', who were goddesses of poetic inspiration. As a body of practice, the 'music' of classical Greece extended to cover all imaginative uses of language and dance, and as an object of theoretical study 'music' was largely the study of scaleconstruction and tuning systems. ${ }^{27}$

In this sense the musical theory was a complete system that explained the totality, from the Cosmos to the souls, from God to mathematics. This was the importance of music in ancient times. In consequence, Islamic thinkers tried to conciliate the classical sciences with the Islamic ones, in a complete paradigm dividing "Science of the Ancients" ('Ulūm al-Awà'il / علوم الأوائل) and "Sciences of the Religion" ('Ulūm al-Dīn / علوم الدين). placed in the former as far as mathematical speculation is concerned. ${ }^{29}$

Accordingly, we can fine in one side the mathematical division of the scale, and in the other, the cosmological description of the Harmony of the Spheres and its effects in mankind. The Cosmos is organized according to proportions and harmonious, based on the distance between the planets. The movements originate the perfect Harmony from the universe to the human souls. Hence, by studying the order of the universe it is possible to hear these harmonies. The musician is in this sense an astrologist that using mathematics describes the nature of the Harmonies, and its division:

The ratios found in musical intervals were sought in the distances of planets, in the compositions of stuffs, in the souls

27 Sparshott and Goehr, "Philosophy of Music", in Stanley Sadie and John Tyrell, Eds., The New Grove Dictionary of Music and Musicians (London: McMillan Press, 2001). Website, www.grovemusic.com.

28 See Jean Jolivet, "Classifications des sciences", in Roshdi Rashed, Dir., Histoire Des Sciences Arabes (Paris: Éditions du Seuil, 1997), vol. 3, pp. 255273. This chapter deals mainly with the classification of the sciences in alKindī, al-Fārābī and Ibn Sīnā. About Ibn Ḥazm classification see Miguel Cruz Hernández, Historia Del Pensamiento en el Mundo Islámico, vol. 2, pp. 363366. See more authors in Osman Bakar, Classification of Knowledge in Islam: A Study in Islamic Philosophies of Science (Cambridge: Islamic Texts Society, 1998).

29 See Jean-Claude Chabrier, "Science musical", in Roshdi Rashed, vol. 2, pp. 231-262. 
of good men and in everything that contributed to cosmic order. Musical structures should thus have analogues in the human mind and in the world at large, and their felt but ineffable meaningfulness should be explicable by those analogies. ${ }^{30}$

When Arabs philosophers found the "Theory of the Spheres" about the perception of the musical phenomena, the sensual and courtesan understanding placed distance between two conceptions of the music. From this point of view, music was the science of the mathematical Harmony of the Cosmos, and must be learned after the speculative method. Thus, we can find elements of this cognition even in the Ikhwān al-Safä' / إخوان الصفاء (Brothers of Purity, c. $10^{\text {th }}$ A.D.), the platonic emanation from the First Motor to the diversity of beings, notion of God as origin of the first movement and harmonious:

The central point in this doctrine [of the Ikhwān al-Safa '] is the heavenly origin and the return of the soul of God. The individual souls are only part of 'the whole-soul' to which they return purified after the death of the body just as the wholesoul will return to God on the Day of the Judgment. ${ }^{31}$

Therefore, with the union of these two ideas - "Theory of the Spheres" and "Theory of the Emanation" the Falsafa made a travel of two directions: from the Cosmos to the souls and from the believer to God. In musical terms, the ë $\theta o \varsigma$ / ethos emerged. Namelly, the "Theory of the Effects" or ethos is the Platonic explanation of how is perceived the universal harmony by the human being. The cosmologic order (active Intellect) is organized in specific proportions and divisions, the octave in consonances, and these consonances produce in the souls (passive Intellect) the same perfect Harmony. In other words, determined scales can produce determined harmony, and due to this transmission of the Idea towards the passive Intellect, it is possible to know how determined music can produce determined moral effect. In brief, ethos is the moral effect caused when hearing a specific musical mode.

30 Sparshott and Goehr, "Philosophy of Music", in Stanley Sadie and John Tyrell, eds., The New Grove Dictionary of Music and Musicians, website, www.grovemusic.com.

31 M. Saeed Sheikh, Studies in Muslim Philosophy, 57. 
The Islamic Falsafa adopted this knowledge, mainly through al-Fārābī (d. 950 A.D.). ${ }^{32}$ If the $I k h w \bar{a} n$ al-Safä' were concerned more with cosmological arguments and mathematical affairs, the works of al-Fārābī follow the way traced by al-Kindī, in terms of applying the Greek methods to the lute as Arabic main instrument (as the Greek did with the lyre). In al-Fārābī we find the major elements of the ancient lore; for instance in the idea as 'Illusion' with a specific moral effect. ${ }^{33}$

Following the works of al-Fārābī three kinds of Music can be noted:

\begin{tabular}{|c|c|c|}
\hline \multicolumn{3}{|c|}{ Species of Music } \\
\hline Greek Tradition & al-Fārābi & Boethius \\
\hline Worldly & Passions & Musica Mundana \\
\hline Human & Imagination & Musica Humana \\
\hline Animal & Pleasure & Musica Instrumentalis \\
\hline
\end{tabular}

The division did by al-Fārābī follows the same patter than Boethius ( $6^{\text {th }}$ A.D.) in the Christian Europe. Boethius as well as al-Fārābī arrived to similar conclusions: the superiority of vocal music. In alFārābi interesting aspects that enrich the classical tradition can be noted; for instance an explanation about musical education, or a well-described analysis of the musical instruments.

Especially relevant is his explanation about the origin of music, using two arguments. Firstly the "Natural history of the music", this is to say, the animal origin of the musical phenomena as communication and transmission of behavioral frames; in this case, the Arabic tradition of the camel. Secondly, a particular "Theory of the Time", the unidirectional time and the necessity to establish structures and breaks in its horizontality. ${ }^{34}$

Indeed, al-Fārābī's thought reconfigures the Arabian tradition into the ethos and the universal Harmony, building a coherent

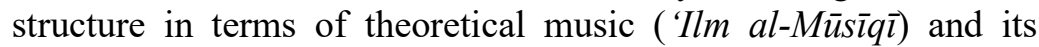
practice and performance ('Ilm al-'Amalī / علم العملي):

\footnotetext{
32 About al-Fārābī see Miguel Cruz Hernández, Historia Del Pensamiento en el Mundo Islámico, vol. 1, pp. 175-210.

33 See D'Erlanger, La Musique Arabe, p. 15.

34 D'Erlanger, La Musique Arabe, p. 18.
} 
As a performer with a reputation, he [al-Fārābī] could bring the 'Ilm al- 'Amali or practical art to bear upon the discussions. So whilst he was more thorough than the Greeks in handing the physical bases of sound, he could also make valuable contributions to physiological acoustics, i.e. the sensation of tone, a question which the Greeks left practically untouched. ${ }^{35}$

Important as well in al-Fārābī was not only to use the classical lore within the frames of the Islamic revelation, but also to increase it with the Central Asian, Persian and Arabic musical traditions. ${ }^{36}$ Consequently, the Islamic philosophical activity about music developed the mathematical and cosmological ideas of the Greeks, but at the same time the facts related with the musical phenomenon as social and human event, as seen in the 'Ilm al-Ghinä'. Going deeper, we can identify in this point the major contribution of alFārābi in contrast with the western dependence on Pythagorean tradition. Indeed, the Theory of the Spheres was a predominant background in western music until the Modern $\mathrm{Era}^{37}$ :

The doctrine that music was or ought to be an 'abstract' system of relationships stateable in a set of equations has haunted musical aesthetics ever since, although the habit of linking music to astronomy by a supposed 'music of the spheres' died with Kepler (1619). ${ }^{38}$

Unlike the division in the West between aesthetics and mathematics, practice and theory, al-Fārābī understood music as an art that must be study under the parameters of science, providing to the music a paradigm that in the West did not obtain until the Romantic period. This pioneering position of al-Fārābī was clearly justified. Thus, it is the artistic nature of the music and its practice what makes to learn the features of the sound and the harmony (mathematical consonance), rather than the inverse. ${ }^{39}$

35 “Mūsīḳ̂̄”, in Brill's First Encyclopaedia of Islam (Leiden: Brill, 1987), vol. VI, p. 751.

36 "Mais, si l'observation les a conduits des pratiques musicales aux systèmes théoriques, les ouvrages qu'ils ont rédigés ont plutôt procédé en sens inverse, de la théorie à la pratique", in Jean-Claude Chabrier, p. 231.

37 The Pythagorean scale system collapsed in the $18^{\text {th }}$ century, when Aristoxenus' tradition was recovered.

38 Sparshott and Goehr, "Philosophy of Music".

39 D’Erlanger, p. 28. 
According to al-Fārābī —and this is his great contribution-, Music is a body that includes two discipline: theory (science: mathematics and acoustics) and practice (art: instruments, organology and performance). As noticed, this conception of the musical phenomena did not appear in Western thought until the moment in which the Romantic spirit gave the change to enjoy the musical aesthetics. In short, al-Fārābī brought up Music to a position that only would be recovered after several centuries, in a pioneering philosophy that understands Music not as a single science, but as group of sciences.

Ibn Bajjah (c. 1080-1138) was the philosopher that received and expanded al-Fārābī's thought in al-Andalus. He wrote extensively on music, melodies, and instruments. ${ }^{40}$ Currently one of his melodies has been affirmed that perhaps influenced the Spanish national anthem. It originated a significant controversy in the Spanish press, about the impact of Andalusian music in the core of Spanish symbols, as the national anthem. ${ }^{41}$

\section{Science of the Number: 'Ilm al-'Adad / علم العدد}

As we have seen, the mathematical interpretation of the Harmony was based in consonances that produce the ethos. In order to arrive to these consonances, it is needed to divide the musical scale according to a mathematical proportion. The different possibilities dividing this scale will give the different theories of the octave, the consonances and the nature of the sound. Due to the mathematical results, the data could be applied to other arena, from the cosmology (Theory of the Spheres) to the psychology (Theory of the Effects). Moreover, the mathematical interpretation of music inserted it within the category of exact science.

From this point we arrive to the "Science of the Number", the number interpreted as origin and nature of the musical and astronomical phenomena. Indeed, this was the main tool used by the

\footnotetext{
40 Owen Wright, "Ibn Bājja [Avenpace]," website Grove Music Online, https://doi.org/10.1093/gmo/9781561592630.article.13679.

41 See for instance David Trueba, "Himnotizados", El Periódico, retrieved February 20 , 2014: $<$ https://www.elperiodico.com/es/opinion/20140220/himnotizados-articulode-david-trueba-3120292>.
} 
Christian philosophers in the Middle Age, especially Saint Augustine, who made a detailed theory about de Numeri Iudicalis.

The role of the number in the musical phenomenon appears as well in the Islamic Falsafa. However, when the Islamic philosophers tried to describe the division of the scale and the nature of the octave, they started using the Pythagorean system, erroneous in itself, and they finished in an instable division adapted to the lute. This is to say, that the errors of the Pythagorean system were faced by the Islamic faläsifa in order to solve the mathematical problem.

What we can denominate as 'Ilm al-'Adadl علم العدد (Science of the Number) has two main aspects. Firstly, it is related with the spheres and the Harmony from the First Motor across the souls. Because there is a cosmological sound, this must be analyzed using the exact proportion with numbers. The universe can be reduced to numbers and its movements (its sounds), are explained by numbers as well:

One of the aims of our treatise on music consists of demonstrating clearly that the whole world in composed in conformity with arithmetical, geometrical and musical relations. There, we have explained in detail the reality of universal harmony. ${ }^{42}$

In this quotation from the Ikhwān al-Safa ' the Pythagorean doctrine clearly appears. The whole world can be reduced to different numerical relations. Music performs an important role due to its numeric nature, and by finding the rules of the musical consonances we can find the rules of the universe. Because this is an Islamized doctrine the rules of the First Motor could be associated with theological arguments about the unity and existence of God. The "Science of the Number" is in this sense the divine knowledge, and to obtain it means to obtain access to all the universal knowledge. This is why in the Pythagorean doctrine and in all the traditions that are influenced by it, the occultism and Hermetic practices can easily emerge. As a result 'Ilm al-Mūsìq $\bar{\imath}$ became finally speculation about the influence of the Harmony in the souls, in other words, Astrology ('Ilm al-Nujūm / علم النجوم):

If any 'ilm is displayed in these later books [ $15^{\text {th }}$ century] it is the 'ilm al-nudjum, and authors fill their pages with

42 Seyyed Hossein Nasr, An introduction to Islamic Cosmological Doctrines (London: Thames and Hudson, 1978), p. 45. 
astrological tables linking up the twelve buyut of the heavens with the twelve makamat, and so forth. ${ }^{43}$

The Islamization of the Theory of the Spheres with the purpose of explaining God's Unity using the mathematical proportions was done by the Ikhwān al-Safā'. They were almost in all the aspects the first that recovered the Greek tradition from the Islamic point of view. The adoption was almost directly, identifying the First Motor with God and the Harmony with the souls: "As for the Ikhwān, number for them is 'the spiritual image resulting in the human soul from the repetition of Unity". ${ }^{4}$

In order to develop the perfect proportions, Music is the answer. Thanks to the division of the scale, the octave, and the quest to find the perfect distance between consonances, Music, Astronomy and Mathematics were understood as the same thing and were developed at the same time. The first argument was about the perfect existence of the number 4 , which became the basis of all the analyses. For instances, the sequence: $1+2+3+4=10$, the 4 elements, the 4 humors, the 4 seasons, the 4 directions or the 4 strings of the instrument. Thus, we arrive finally to the most important issue in the ancient philosophy of music: the tetra-chord. The division of a string, from its total dimension until its center, produces the same sound, the octave (1/2). From this division, we can divide the middle again, appearing two divisions: the forth (3/4) and the fifth (2/3). Because always remains a space between this two consonances, in order to fill the number of the octave it is necessary to add an adjustment (8/9), the so-called Pythagorean Comma.

The Islamic philosophers found in this adjustment also the main issue to speculate about the perfect division of the scale and the nature of the consonances. The problem increased because the Greek theory, original made for lyre, was adapted to the lute, with other tuning and practice. Moreover the mathematical problem was aggravated when al-Kindī added a fifth string in the lute. ${ }^{45}$ Finally, al-Fārābī was the one who obtained a well-explained division of the scale, after whom the falassifa had elements to consolidate the own

\footnotetext{
43 "Mūsīḳ̄", in Brill's First Encyclopaedia of Islam, vol. VI, p.748.

44 Hossein Nasr, An introduction to Islamic Cosmological Doctrines, p. 49.

45 "Mūsīḳ̂̄”, in Brill's First Encyclopaedia of Islam, vol. VI, p.751.
} 
musical system, the systematization of the Islamic music until the contemporary era, moment in which the Western system altered it. ${ }^{46}$

\section{Science of the Audition: 'Ilm al-Simä' / علم السماع}

Finally, if the musical phenomenon was understood as Harmony from the cosmos to the souls according to mathematical proportions, these souls could do the other way back towards the Harmony. The work done by the falāsifa was to describe the nature and production of music, but the process of reception remained unclear. Thus, the proportional harmony could show us the presence of the First Composer, without doubts an intuitive process near to mysticism. After the theorization of the IIm al-Mīsíqi the gate was opened to the concrete explanation of the spheres, the number and the Harmony of the cosmos, in other words, the gate was reveled (Kashf / كشف "The act of lifting and tearing away the veil"). 47

As a matter of fact, the Theory of the Spheres in its Islamic fashion was clear about the nature of the Harmony as God. Musical consonances could be the perfect way to adhere in the soul the remembrance of the origin - the Dhikr / ذكر:

Our musics are the echo of the hymns which the spheres sing as they revolve $[\ldots]$ The song of the worlds which evolve, this is what men try to reproduce with the lute and with the voice. We have all heard the lofty melodies in the paradise which we have lost, and although the earth and the water have overwhelmed us, we retain our memory of the song of the sky. He who loves feeds his love by listening music, for music reminds him of the joys of his first union with God. ${ }^{48}$

In this paragraph all the different interpretations about the musical phenomenon that we have been analyzing appear. The

46 “À partir du XVIIIè siècle, le monde arabo-persan a subi l'impact de la rencontre avec un Occident plus fort sous forme d'un compromis d'écriture musicale représenté par des portées européennes et des altérations en quarts de ton. C'est désormais ainsi que l'on enseigne et diffuse les musiques arabes", in Jean-Claude Chabrier, pp. 261-262.

47 See Leonard Lewisohn, "The Sacred Music of Islam: Sama' in the Persian Sufi tradition”, British Journal of Enthomusicology, Vol. 6 (1997), pp 1-33.

48 Quotation from Rūmī in Emile Dermenghem, Muhammad and the Islamic Tradition, p. 173. 
mystic tried to have in mind a complete paradigm, the reconfiguration of all the life moved by music. In this text of Jalāl al-Dīn Rūmī (d. 1273 A.D) the concept of Dhikr (to remind, to retain) appears, a remembrance about the origin of our soul and our final end. Because the movement of the spheres, because the sound its produces, the music can remind us the first union, and using this remembrance (dikhr) the gate became open and the way reveled (kashf). Hence, there is a necessity of music in mystical practices, and accordingly mystical schools as the Dervish evolved. ${ }^{49}$

The same could be said about Ibn 'Arabī (1165-1240 A.D.). Where Rūmī uses the Theory of the Spheres and the Harmony to explain the concept of Dhikr, Ibn 'Arabi uses the mathematical proportion of the number four and the Theory of the Ethos:

Nature is fourfold, with subjects and objects, and active and passive: there are four directions and four humours, to which correspond four basic musical sounds, which make them (the humours) move and produce musical pleasure. The pleasure of this sounds and their effect on characters have their root in the divine Word. He who hears a sound suited to his temperament cannot escape from its influence. ${ }^{50}$

This mention points out the effects in the soul and the origin of the music in mathematical proportions, all related at the same time with psychological and cosmological arguments. But also we can find Fārābian contributions, the aesthetics in the musical phenomenon as artistic event. Therefore, a very coherent theory from different origins and with different purposes consolidated for the $13^{\text {th }}$ century.

At the end, the Islamic thought about the musical phenomenon, after a long process of absorbing different and heterogeneous traditions, was able to build an own theoretical body in which Music appeared in a coherent structure. From the pre-Islamic Arabia and Persian traditions, from the Qur'ānic recitation, the Greek Philosophy was featured in modern words. The Islamic civilization created a very remarkable and rich paradigm about Music, a

49 J. During, "Musique et rites: le samâ'", in G. Veintein and A. Popovic. Eds., Les voies d'Allah. Les ordres mystiques dans le monde musulman des origines à nos jours (Paris: [s.e.], 1996).

50 Emile Dermenghem, Muhammad and the Islamic Tradition, 169. 
philosophical paradigm with different sciences that was the deepest musical thought until the $17^{\text {th }}$ century.

As it is well known, Sufism achieved in al-Andalus the highest level with the role of Ibn 'Arabi (1165-1240), author of the monumental Al-Futūhāt al-Makkiyya. The influence of Islamic mysticism in Spanish Christian culture has been validated by many scholars in many aspects, between others over the mystic poetry of San Juan de la Cruz. ${ }^{51}$

\section{Juan Andrés on Arabic Music}

The importance of the «Letter on Arabic music» by the Jesuit Juan Andrés, a short letter consisting of three paragraphs - two in Italian and a Latin quote from the Bibliotheca Arabico-Hispana Escurialensis by Miguel Casiri- has not been sufficiently stressed. It was addressed to Giambatista Toderini and published between pages 249 and 252 of volume 1 of Letteratura turchesca, "Turkish Literature" (Venice, Giacomo Storti, 1787). The frugality of the epistolary genre and the fortune that accompanied the reception of Dell'origine, progressi e stato attuale d'ogni letteratura (Parma, Stamperia Reale, 1782-1799) have historically obscured the place that rightfully corresponds to this small note. Indeed, it can be said quite certainly that this epistle constitutes one of the first modern European texts that deals about the history, theory and instrumental practice of Arabic music. And despite its brevity it deals about the fundamental aspects of musicological reflection: history, theory, organology and interpretation.

Toderini's Letteratura turchesca was not a minor text, and the fact that Juan Andrés' letter was directly reproduced showed the great respect that the Spanish Jesuit had in Italian circles. Andrés was in direct contact with Miguel Casiri (1710-1791), Maronite priest that published in two volumes the catalogue of Arabic manuscripts in the royal library of El Escorial (1760-1770). A partial copy of the Kitāb al-Mūsīqì al-Kabīr / كتاب الموسيقى الكبير ("Great book of music") by Abū Nașr Muḥammad al-Fārābī / appeared in this library. It was a partial copy done

51 Luce Lopez-Baralt, San Juan de la Cruz y el Islam (Madrid: Hiperión, 1990). 
by the scribe Abū-l-Hasan ibn Abū Kamāl of Cordoba, and it seems to be that the copy belonged to the philosopher Abū Bakr Muḥammad ibn Yahyyà ibn al-Șā'ig ibn Bājja / أبو بكر محمد بن يهيى Avempace is considered the first Andalusian thinker of Hellenic tradition and is the commentator of the works of Aristotle and al-Fārābī. The text in question was entitled Istiqsāt 'ilm al-mūsīqī / اسطقسات علم الموسيقي (Breviary on Music Science). Casiri deals about this manuscript and provides the Latin translation of Musices Elementa, in the number CMVI of the page 347 of the first volume of his Bibliotheca, shortly after having dealt extensively, in Arabic and Latin, with the life and works of Mohamad Ben Mohamad Ben Tharkhan Abu Nasser Alpharabius (pp. 189-192) $)^{52}$.

Between the hundreds of manuscripts preserved in the library of El Escorial, Juan Andrés placed his attention in this with admirable insight. Consequently, he asked Casiri to deliver him an extract. And so the commission arrived to the disciple José Antonio Banqueri:

Don Miguel Casiri tried to direct me in the study of the Arabic language, and to exercise myself in the reading and management of some manuscripts. Among which was one of Alfarabi that deals with music, and whose fragment, which belongs to the royal library of El Escorial, commissioned me to form an excerpt with the Spanish translation that Mr. Abate Andrés had requested, then resident in Italy and author of the work entitled Origin, progress and current state of all literature ${ }^{53}$.

52 Manuscript currently in the National Library of Spain: [RES / 241], with digital reproduction in Biblioteca Digital Hispánica: <http://bdhrd.bne.es/viewer.vm?id=0000008621\&page $=1>$. To our knowledge, it is still waiting for a modern edition and translation. A partial Spanish translation was done by José Antonio Conde and appeared in the volume of Mariano Soriano Fuertes, Música árabe-española y conexión de la música con la astronomía, medicina y arquitectura (Barcelona: Juan Oliveres, 1853).

53 Our translation from Kitāb Al-filāhat mu'allifu-hu al-shayj al-fādil Abū Zakarīyā Yahyà ibn Muhammad ibn Ahmad Ibn al- 'Awwām al-Ishbìlī. Libro de agricultura, su autor el doctor Abu Zacaria Iahia aben Mohamed ben 
Thus, it is Juan Andrés who selected from the hundreds of manuscripts cataloged by Casiri that one of al-Fārābī. History proved that he was right, since it is a fundamental piece to explain the course of Arabic music, and Juan Andrés is probably the first European author to realize it. And it was fundamental to prove his major thesis: the Arab contribution to the development of Western knowledge, science and art, and why the European Renaissance cannot be explained without the Arab achievements transmitted by the Andalusian culture ${ }^{54}$ :

Is it not, then, probable that if the first vulgar songs put into music were the songs of King Alfonso, we should take from the Arabs the principle of modern music not less than that of Poetry? And who could at that time give the learned Monarch such an example but the Arabs, who frequently used it in their books? This becomes more plausible knowing that the Spaniards took some musical instruments from the Arabs, which are still preserved today, and that others, not only among the Spaniards, but also among the French, were called "Moriscos", which proves more and more how much influence Arabic music had in Europe and how much our culture still owes in this part to the studies of that nation so despised ${ }^{55}$.

The letter on the Arabic music of Juan Andrés, dated in Mantua, March 29, 1785, written in Italian language and reproduced in Toderini's Letteratura turchesca, represents a pioneering text of musicological reflection, in its fundamental aspects: 1) basic account of Arabic musical thought (first and second paragraphs, work of al-Fārābī and his Andalusian reception by Ibn Bajja); 2) musical organology (relation of instruments: rabāb or rabel, šarūd or archilaúd); 3) musical theory (consonant intervals, Greek influence); and 4) musical practice (graphics and tables added to illustrate the interpretation, materials not reproduced by Toderini, but which Juan Andrés explicitly states that he sent next to the

Ahmed Ebn el Awam sevillano; traducido al castellano y anotado por Josef Antonio Banqueri (Madrid, Imprenta Real, 1802), p. 12.

54 See I. Donoso, "El arabismo de Juan Andrés", en Pedro Aullón de Haro y Jesús García Gabaldón, Eds., Juan Andrés y la Escuela Universalista Española (Madrid: Ediciones Complutense, 2017), pp. 165-175.

55 Juan Andrés, Origen, progresos y estado actual de toda la literatura, traducción de Carlos Andrés, Pedro Aullón de Haro, Ed. (Madrid, VerbumBiblioteca Valenciana, 1997), vol. 1, p. 240. 
letter). In short, one final goal of his major project which is succinctly encapsulated in the epistle - is to justify the influence of Andalusian music in the constitution of profane and popular music of peninsular Christians and, in extension, in Western Europe.

\section{LETTER ON ARABIC MUSIC}

Mantua, March 29, 1785

I have finally seen the desired prospect of his interesting work in the Novelle Letterarie in Florence, and with great joy I anticipate the most sincere and friendly congratulations. If Leibniz had in great consideration the small and little digestible work of Donado on the Literature of the Turks, which he valued more relevant than the other works he had seen in Venice, what would he have said if he had seen the vast and learned work that with same argument you have prepared? I wish you health and comfort to carry it out and publish it, and I look forward to it. I appreciate the information that you kindly provide me. About the clock of the Arabs (or pendulum) I mentioned myself some books to Casiri, asking him to consult them, but his advanced age has not allowed it, and the fact to be these codices in El Escorial, some miles far from Madrid, makes your query even more difficult. Regarding the al-Farābī codex, you are right to say that it is not an autograph but a copy, which Kamel took from an old Zaragoza codex of Aben Pace [Ibn Bajja], his teacher. These are Casiri's words:

Codex litteris Cuphicis exaratus Cordubae absque anni nota in quo habetur opus clarissimi Philosophi Abi Nesser Mohamad Ben Mohamad Al Pharabi, cujus vitam supra citavimus inscriptum Musices Elementa in tres partes divisum: in quarum prima de hujusce artis principiis; secunda de compositione tum vocum, tum instrumentorum; tertia de vario compositionum genere disseritur, adjectis notis musicis, \& instrumentorum figuris plus triginta. Hunc codicem ex alio pervetusto Philosophi gravissimi Caesaraugustani Abì Baker Ben Alsalegh Ebn Bageh, vulgo Aben Pace, descripsisse se testatur Abilhassonus Ben Abì Kamel Cordubensis, ejusdem 
Aben Pace auditor. Quare codicem hunc intra annum Egirianum 525 exaratum fuisse propius vero est, cum eo ipso anno Aben Pace decessisse memoriae proditum sit.

Since I received myself a small excerpt from this codex, I found in it some figures of thirty musical instruments that were seen in that codex, and others of musical compositions. The instrument mentioned here is al-Chaherud, invented in Samarkand by Hakim Ben Ahrias. There are also some others of string and wind. Some tables of al-Farābī are also included, in which he explains the musical economy of some instruments. I have considered it appropriate to copy at the end of this letter the figure of an instrument called al-Rabab and the Harmony of the vocals of 15 strings in $4^{\text {th }}, 5^{\text {th }}$ and $8^{\text {th }}$, but never in $3^{\text {rd }}$. This may perhaps shed some light on Greek Music, since it is seen throughout the codex that the musical doctrine of the Arabs is derived from that of the Greeks. I also want to copy the prospectus of your work and send it to Spain: if it will produce some reactions, I will communicate it to you without fail. Meanwhile you see that, if some figures could be added, some were from al-Farābī indeed. Be that as it may, these figures were used by the Arabs. I have particularly appreciated the news that you offer me from Mr. de Villoison and the Count of Choiseul Gouffier. If you have other similar news to communicate, or requests to make me, it will be an honor to attend to them, professing my deepest esteem, etc.

\section{Conclusions}

The Arabic Theory of the Spanish Jesuit Juan Andrés clearly stated the role of al-Andalus in the definition of important cultural trends in early modern Europe. Giovanni Maria Barbieri spoke about the Arab influence in the development of Rhymed poetry two centuries earlier. Farmer detailed the transmission of Arabic musical theory and instruments to the West, and Ribera indicated that the European musica ficta was certainly Arabic-influenced music. In this paper we have tried to provide a preliminary approach to the major musical sciences from the point of view of the Islamic thought. Our goal has been to obtain a general picture of a significant tradition that use to be obliterated, certainly in a general narrative of Western music. But al-Andalus was a Western nation, and Andalusian culture influenced the ulterior Spanish developments. During the 
Enlightenment, Juan Andrés interpreted the feasible relevance of Arabic elements to fully understand the European Renaissance, including music. His letter on Arabic music sent to Giambatista Toderini in March 29, 1785, and reproduced in the volume Letteratura turchesca, represents a short but significant hint to rewrite the historiography and substantiate the Andalusian transmission.

\section{Bibliography}

"El arabismo de Juan Andrés". Juan Andrés y la Escuela Universalista Española, Eds.. Pedro Aullón de Haro and Jesús García Gabaldón, Madrid: Ediciones Complutense, 2017.

"Mūsīḳ̂̄”, in Brill's First Encyclopaedia of Islam. Leiden: Brill, $1987 .$.

A.F.L. Beeston, Al-Jahiz. Epistle on Singing Girls. Warminster: Aris \& Philips, 1980.

Al-Ganabī, Wilhelmina Wagner de. "La Escuela Coránica De Denia: Abū 'Amr 'Utmān B. Sa '̄̄ Al-Dānī: Figura, Obra Formativa Y Obra Escrita". PhD, Granada, University of Granada, 1988.

Al-Zayāt, Aḥmad Ḥasan. Tārīkh al-Adab al- 'Arabī. Beirut: Dār alThaqāfa,n.d.).

Andrés, Juan. Origen, progresos y estado actual de toda la literatura, traducción de Carlos Andrés, Ed. Pedro Aullón de Haro. Madrid, Verbum-Biblioteca Valenciana, 1997.

Bakar, Osman. Classification of Knowledge in Islam: A Study in Islamic Philosophies of Science. Cambridge: Islamic Texts Society, 1998.

C. Huart, Littérature Arabe. Paris: Colin, 1931.

Carra de Vaux, "Preface", in Rodolphe D'Erlanger, La Musique Arabe. Paris: Librairie Orientaliste Paul Geuthner, 1930.

Cook, Nicholas. Music, Imagination, and Culture. Oxford: Clarendon, 1990.

Cortes, Manuela. La Música árabe y Andalusí de las Dos Orillas en Los Estudios Musicológicos (ss. XVIII-XXI). Granada: Ediciones del Genal, 2018.

Dainotto, Roberto M. "The Discreet Charm of the Arabist Theory: Juan Andrés, Historicism, and the De-Centering of 
Montesquieu's Europe", European History Quarterly 36, No. 1 (2006), pp. 7-29.

Dell'Origine Della Poesia Rimata. Modena: Presso la Società Tipografica, 1790.

Dermenghem, Emile. Muhammad and the Islamic Tradition. New York: Overlook Press, 1981.

Donoso, I. "El arabismo de Juan Andrés", en Pedro Aullón de Haro y Jesús García Gabaldón, Eds., Juan Andrés y la Escuela

Universalista Española. Madrid: Ediciones Complutense, 2017.. During, J. "Musique et rites: le samâ'", in Eds., G. Veintein and A.

Popovic. Les voies d'Allah. Les ordres mystiques dans le monde musulman des origines à nos jours. Paris: n.pb., 1996.

Encyclopaedia of Islam. Leiden: Brill, Second Edition, 1986.

Farmer, Henry George. Historical Facts for the Arabian Musical Influence. London: William Reeves, 1930.

Hernández, Miguel Cruz. Historia Del Pensamiento en el Mundo Islámico. Madrid: Alianza, 1996.

Historia De La Música Árabe Medieval Y Su Influencia En La Española. Madrid: Voluntad, 1927.

Ibn Qutaiba, Introduction au Livre de la Poésie et Des Poètes. Paris: Belles Lettres, 1947.

Israel Katz, Henry George Farmer and the First International Congress of Arab Music (Cairo 1932). Leiden: Brill, 2015. Jolivet, Jean. "Classifications des Sciences", in Roshdi Rashed, Dir. Histoire Des Sciences Arabes. Paris: Éditions du Seuil, 1997.

José Antonio Conde and appeared in the volume of Mariano Soriano Fuertes, Música árabe-española y conexión de la música con la astronomía, medicina y arquitectura (Barcelona: Juan Oliveres, 1853).

Kilpatrick, Hilary. "Princes, Musiciens at Musicologues À La Cour Abbaside", in Les intellectuels en Orient musulman. Statut et Function. Cairo: Institut Français d'Archéologie Orientale, 1999.

Kitāb al-Aghān̄i. Beirut: Dār Ihyā' al-Turāth , n.d..

Kitāb al-Aghānī. Cairo: Dār al-Kitāb al-'Arabī, 1970-1974.

Kitāb Al-filāhat mu'allifu-hu al-shayj al-fādil Abū Zakarīyā Yahyà ibn Muhammad ibn Ahmad Ibn al- 'Awwām al-Ishbīlì. Libro de agricultura, su autor el doctor Abu Zacaria Iahia aben Mohamed ben Ahmed Ebn el Awam sevillano; traducido al 
castellano y anotado por Josef Antonio Banqueri. Madrid, Imprenta Real, 1802.

La musique arabe, ses rapports avec la musique grecque et le chant grégorien (Algeria: Adolphe Jourdan, 1879).

Lewisohn, Leonard. "The Sacred Music of Islam: Sama" in the Persian Sufi tradition”. British Journal of Enthomusicology, Vol. 6 (1997), pp 1-33.

Luce Lopez-Baralt. San Juan de la Cruz y el Islam. Madrid: Hiperión, 1990.

Meregalli, Franco. "Andrés, Herder y el arabismo", Spanien und Europa im Zeichen dar Aufklärung. Ed. Siegfried Jüttner,. Frankfurt am Main: Meter Lang, 1991.

Merriam, Alan. The Anthropology of Music. Evanston: Northwestern University Press, 1964.

Nasr, Seyyed Hossein. An introduction to Islamic Cosmological Doctrines. London: Thames and Hudson, 1978.

Saadé, Gabriel. "L'histoire de la Musique Arabe", Bulletin d'Etudes Orientales, No. XLV (1993), pp. 201-220.

Sheikh, M. Saeed. Studies in Muslim Philosophy. Lahore: Muhammad Ashraf, 1974.

Siddiqui, Abdul Hameed. The life of Muhammad. Calcutta: Hilal Publications, 1982.

Sparshott and Goehr. "Philosophy of Music", in Eds. Stanley Sadie and John Tyrell. The New Grove Dictionary of Music and Musicians. London: McMillan Press, 2001.

Taqī-ud-Din Muhammad, al-Hilālī and Khān, Muhammad Muhsin. Translation of the Meaning of the Noble Qur'ān in the English Language. Medina: King Fahd Complex for the Printing of the Holy Qur'ān, 1996.

Touma, Habib. The Music of the Arabs. Portland: Amadeus, 1996.

Trueba, David. "Himnotizados", El Periódico, retrieved February 20 , 2014:

$<$ https://www.elperiodico.com/es/opinion/20140220/himnotiz ados-articulo-de-david-trueba-3120292>.

Vaux, Carra de. Les penseurs de l'Islam. Paris: Librairie Paul Geuthner, 1923.

Zwartjes, Otto and Henk Heijkoop Muwaššah, Zajal, Kharja: Bibliography of Eleven Centuries of Strophic Poetry and Music 
from al-Andalus and their Influence on East and West Leiden: Brill, 2004.

Iconographic Appendix

$$
250 \text { S T U D J }
$$

al Casiri varj libri, pregandolo di consultarli, ma l'avanzata età non glielo ha permesso, e il trovarsi detti Codici nell'Escuriale, lontano molte miglia da Madrid, lo difficulta ad ogni altro: Rispetto al Codice di Farabio, ella ha ragione, che non eे autografo, ma copia, che Kamel cavò da un codice antico di Saragozza d' Aben Pace suo maestro. Ecco le parole del Casiri: Codex litteris Cuphicis exaratus Cordubx absque anni nota in quo habetur opus clarissimi Philosophi Abi Nesser Mohamad Ben Mohamad Al Pharabi , cujus vitam supra citavimus ( al parlare $d^{\prime}$ una Enciclopedia dello stesso Alfarabi, ne riporta la sua vita cavata dalla Biblioteca de' Filosofi ) inscriptum Musices Elementa in tres partes divisum: in quarum prima de hujusce artis principiis; secunda de compositione tum vocum, tum instrumentorum ; tertia de vario compositionum genere disseritur, adjectis notis musicis, \& instrumentorum figuris plus triginta. Hunc codicem ex alio 
252. S T U J

forse potrà dar qualche lume sulla Musica Greca, massimamente vedendosi in tutto il codice, che la dottrina Musica degli Arabi era cavata da' Greci. Voglio pure copiare il Prospetto della sua opera, e mandarla in Ispagna, e se questo produrra qualche notizia su alcuno de' punti da lei trattati, gliela comunicherd. In tanto ella vede, che se bene alcune figure possono essere state ag. giunte, altre debbono essere di Farabio, e ad ogni modo si trovano usate dagli Arabi tali figure. Mi sono state parimente care le notizie, ch'Ella $\mathrm{mi}$ ha favorite di $\mathrm{Mr}$. de Villoison, e del Conte de Choiseul Gouffier. S'Ella avrà altre simili notizie da camunicarmi, o comandi da farmi, me ne farà grazia, professandomi colla più vera stima, ecc. ",

Fine del Tomo Primo.

\section{IN.}

Pages of Andrés' letter included in Giambatista Toderini, Letteratura turchesca (Venice, Giacomo Storti, 1787), pp. 249-252 


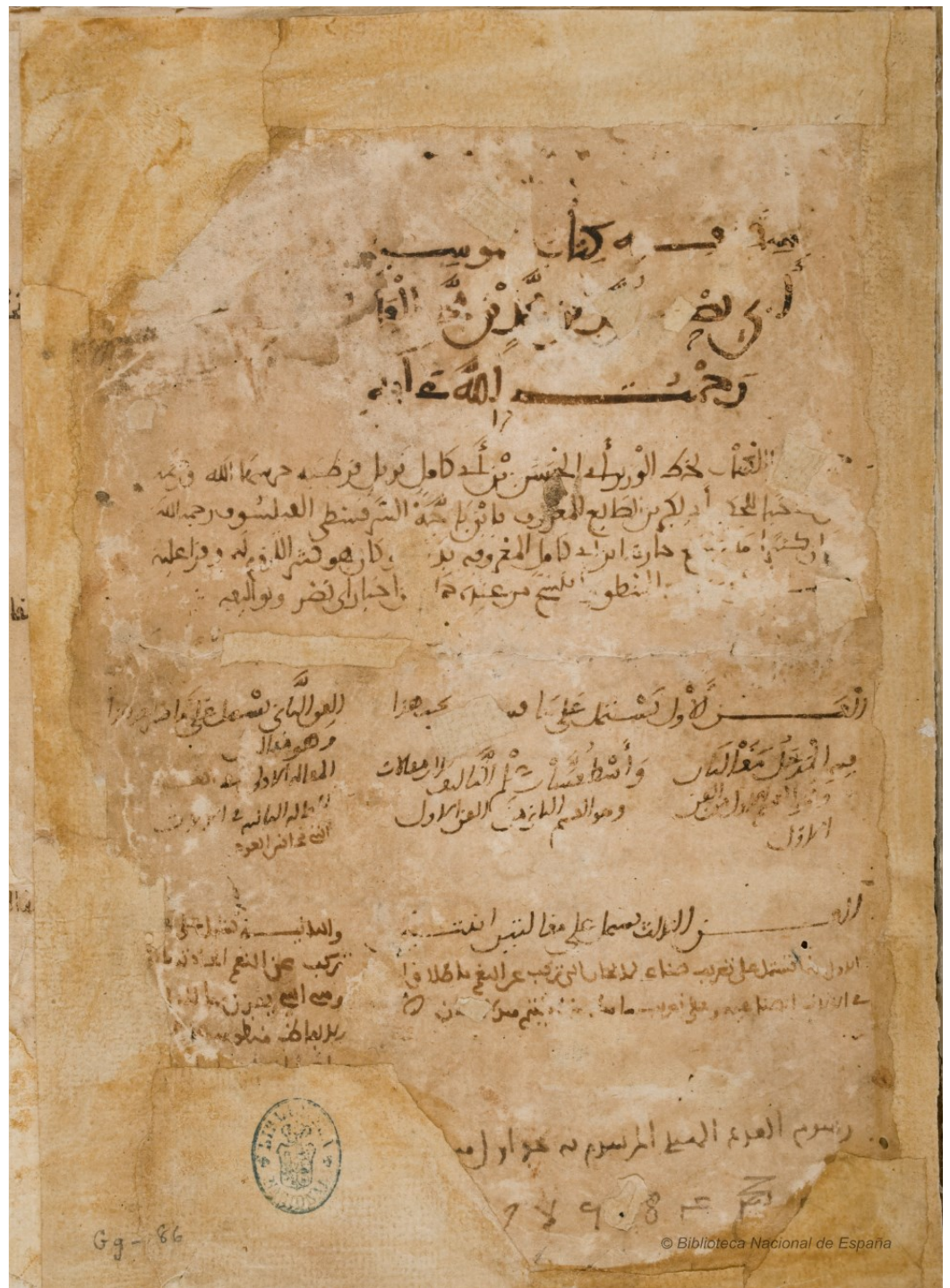

Manuscript of Abū Nașr Muhammad al-Fārābī on Music [Biblioteca Nacional de España: RES / 241] 